\title{
TATA KELOLA PERUSAHAAN DAN VARIABILITAS LABA
}

\author{
Ikka Tiaraintan Hariyanto \\ Novrys Suhardianto \\ novrys@feb.unair.ac.id \\ Fakultas Ekonomi dan Bisnis Universitas Airlangga
}

\begin{abstract}
This research aims to examine the influence of firm size, leverage, and corporate governance on earnings variability. We relate the earnings variability with the hypotheses of positive accounting theory and governance mechanism in Indonesia to identify factors that influence earnings variability. Using purposive sampling, we got 628 observations of Indonesian public firms during 2012 until 2014. This research uses common and fixed effect regression model to analyse the data. The results of this analysis show that the big firms have higher profit variability due to higher business and political risks. However, this finding applies only to samples with weak governance. Moreover, the greater the debt the company has, the greater the level of profit variability. This is due to the company's incentives to avoid breaching the debt contract, such as maintaining debt to equity ratio, working capital, or shareholder equity, by adopting aggressive accounting policies. Lastly, the CG mechanism does not affect the variability in earnings, indicating the lack of effective corporate governance in Indonesia. The CG mechanism in Indonesia has not generally been able to influence financial reporting behavior and capital market regulators need to take action to improve the effectiveness of corporate governance in Indonesia.
\end{abstract}

Key words: earnings variability; firm size; leverage; corporate governance; earnings smoothing

\begin{abstract}
ABSTRAK
Penelitian ini bertujuan untuk menguji pengaruh ukuran perusahaan, leverage, dan tata kelola perusahaan terhadap variabilitas laba. Penelitian ini menjelaskan variabilitas laba dengan hipotesis teori akuntansi positif dan mekanisme tata kelola perusahaan di Indonesia untuk mengidentifikasi factor-faktor yang akan memengaruhi variabilitas laba. Dengan menggunakan purposive sampling, 628 observasi diperoleh dari bursa efek Indonesia selama 2012 sampai 2014. Hasil analisis ini sesuai dengan hipotesis teori akuntansi positif bahwa ukuran perusahaan yang semakin besar menghadapi risiko bisnis dan politik yang besar sehingga variabilitas laba meningkat. Namun demikian, hal ini hanya berlaku pada sampel dengan tata kelola yang lemah. Lebih jauh, semakin besar kontrak hutang yang dimiliki perusahaan maka semakin besar tingkat variabilitas laba. Hal ini disebabkan oleh adanya insentif perusahaan untuk menghindari pelanggaran kontrak hutang, seperti mempertahankan rasio hutang atas modal, modal kerja, ataupun ekuitas pemegang saham, dengan mengadopsi kebijakan akuntansi yang agresif. Terakhir, mekanisme CG tidak mempengaruhi variabilitas laba menandakan belum efektifnya tata kelola perusahaan di Indonesia. Mekanisme CG di Indonesia secara umum belum mampu mempengaruhi perilaku pelaporan keuangan dan regulator pasar modal perlu mengambil tindakan untuk meningkatkan efektifitas tata kelola perusahaan di Indonesia.
\end{abstract}

Kata kunci: variabilitas laba, ukuran perusahaan, tingkat hutang, tata kelola perusahaan, perataan laba

\section{PENDAHULUAN}

Menurut Kerangka Konseptual Pelaporan Keuangan (Ikatan Akuntan Indonesia, 2016), terdapat empat karakteristik kualitatif laporan keuangan yaitu dapat dipahami, relevan, keandalan, dan dapat dibandingkan. Karakteristik relevan dan dapat dibandingkan mengharuskan pihak manajemen perusahaan bertanggung jawab atas pemberian informasi yang mendukung 
prediksi posisi keuangan masa depan. Dengan demikian, kinerja keuangan yang stabil lebih disukai investor karena menghasilkan prediksi yang lebih tepat. Para pemegang saham dan kreditur mengharapkan informasi laba yang dapat digunakan untuk memperkirakan earnings power serta memprediksi laba di masa yang akan datang (Siallagan dan Machfoedz, 2006). Pergerakan laba dapat menggambarkan efektifitas kebijakan yang telah diterapkan oleh manajer. Pergerakan laba yang stabil menandakan semakin baik pengelolaan perusahaan karena dapat memberikan jaminan kepastian aliran masuk sumber daya kepada pihak yang berkepentingan. Dengan demikian, laba yang stabil meningkatkan fitur prediktibilitas laba.

Laba yang merata (smoothness) merupakan salah satu atribut penilaian berdasarkan accounting-based yang berarti laba berkualitas apabila mengandung variabilitas yang kecil atau smooth (Dechow et al., 2010). Perataan laba bisa meningkatkan persistensi dan keinformatifan laba. Kendati demikian, perataan laba bisa menjadi obyek pengelolaan oleh manajemen alih-alih mencerminkan stabilitas operasi perusahaan.

Manajer bisa menggunakan metode akuntansi yang akan mendukung pengambilan keputusan yang optimis, seperti alokasi biaya, transfer pricing, atau perencanaan modal (Tang dan Chang, 2015) dengan menyetabilkan laba. Namun demikian, Matsuura (2008) menyatakan bahwa selama manajer menggunakan keleluasaan mereka dalam batasan-batasan yang di berikan oleh prinsip akuntansi berlaku umum, manajemen laba bukanlah hal yang ilegal. Oleh sebab itu, penelitian perlu memprediksi perataan laba yang merupakan hasil diskresi manajerial.

Watts dan Zimmerman (1986) telah mengembangkan tiga hipotesis berdasarkan pendekatan positif untuk memprediksi pemilihan metode akuntansi dalam konteks manajemen laba. Tiga hipotesis teori akuntansi positif menurut Watts dan Zimmerman, diantaranya adalah Bonus Plan Hypo- thesis (hipotesis rencana bonus); Debt-Covenant Hypothesis (hipotesis kontrak hutang); dan Political Cost Hypothesis (hipotesis biaya politik). Sebagai tambahan, good corporate governance (GCG) diharapkan dapat menekan perilaku oportunis manajemen perusahaan yang menjadi asumsi implisit teori akuntansi positif (Hopt dan Leyens, 2004). Perilaku oportunis manajemen muncul karena pemegang saham selaku principal tidak mampu secara langsung mengawasi usaha dan kinerja manajemen sebagai agen. Dengan demikian, GCG akan mengendalikan konflik kepentingan antara agen dan prinsipal dalam teori agensi.

Hasil penelitian ilmiah tiga hipotesis teori akuntansi positif dan GCG dalam menjelaskan manajemen laba belum menunjukkan hasil yang konsisten (Suhardianto dan Harymawan, 2011; Suhardianto et al., 2017). Sebagai contoh, Pagalung dan Sudibdyo (2012) serta Lassaad dan Khamoussi (2013) meneliti pengaruh ukuran perusahaan, sebagai proksi biaya politis, dan kontrak hutang terhadap perataan laba, namun dengan hasil yang berbeda. Penelitian mengenai pengaruh Good Corporate Governance terhadap kualitas laba dilakukan oleh Sivaramakrishnan dan Yu (2008) serta Yushita dan Triatmoko (2013) dan belum menunjukkan hasil yang konsisten.

Penelitian ini bertujuan menguji kembali kemampuan teori akuntansi positif dan mekanisme GCG dalam menjelaskan variabilitas laba. Penelitian ini berbeda dengan penelitian sebelumnya karena menggunakan proksi smoothness dalam mengukur variabilitas laba suatu perusahaan yang berupa variabel continuous. Pada umumnya, penelitian perataan laba menggunakan variabel dummy dengan mengelompokkan sampel menjadi perata dan bukan perata laba (Suhardianto dan Harymawan, 2011). Secara khusus, penelitian ini menggunakan proksi kualitas audit yang dikembangkan oleh Herusetya (2012) sebagai bagian dari mekanisme GCG. Pengukuran kualitas audit ini menangkap secara lebih komprehensif dimensi kualitas audit. 


\section{TINJAUAN TEORETIS \\ Teori Akuntansi Positif}

Tujuan teori akuntansi positif adalah menjelaskan dan memprediksi praktik akuntansi. Teori yang dirumuskan oleh Watts dan Zimmerman (1978) terdiri dari tiga hipotesis yang bisa digunakan menjelaskan perilaku oportunistik manajemen. Dua hipotesis pertama kerap dikenal dengan istilah hipotesis kontraktual karena terkait kontrak kompensasi manajerial maupun kontrak utang. Pertama, hipotesis rencana bonus (bonus plan hypothesis) memprediksi bahwa para manajer cenderung akan lebih memilih prosedur akuntansi yang akan menggeser pendapatan periode mendatang ke periode yang sedang berlangsung untuk memaksimalkan bonus atau kompensasi manajerial sejenis. Holthausen et al. (1995) telah membuktikan bahwa manajemen cenderung mengelola praktik akuntansi untuk kepentingan bonus. Namun demikian, riset kontrak kompensasi manajerial di Indonesia belum terdokumentasi dengan baik. Suhardianto dan Harymawan (2011) mendokumentasi bahwa hanya terdapat satu artikel terpublikasi di jurnal terakreditasi yang menguji hipotesis bonus. Hal ini bisa jadi disebabkan terbatasnya pengungkapan dalam laporan keuangan yang berkaitan dengan bonus maupun kompensasi manajerial sejenis.

Kedua, hipotesis kontrak hutang (debt covenant hypothesis) menjelaskan bahwa perusahaan yang memiliki rasio debt to equity yang tinggi cenderung memilih prosedur akuntansi yang akan menggeser pendapatan periode mendatang ke periode saat ini untuk mempertahankan rasio hutang atas modal, modal kerja, ekuitas pemegang saham, dan sebagainya. Lassaad dan Khamoussi (2013) menunjukkan bahwa financial leverage tidak berpengaruh terhadap perataan laba. Namun demikian, Yusuf dan Soraya (2004) menemukan bahwa leverage berpengaruh terhadap perataan laba.

Ketiga, hipotesis biaya politik (political cost hypothesis) menyatakan bahwa semakin besar ukuran perusahaan semakin besar kemungkinan manajer perusahaan untuk menangguhkan pendapatan yang diterima pada tahun ini ke pencatatan periode selanjutnya untuk mempertahankan reputasinya di depan publik. Pembuktian biaya politik secara khusus lepas dari pengaruh ukuran perusahaan merupakan tantangan bagi riset di masa depan. Dengan demikian, bukti bahwa ukuran perusahaan berpengaruh terhadap perataan laba cenderung tidak konsisten. Sebagai contoh, Salno dan Baridwan (2000) menunjukkan bahwa ukuran perusahaan tidak berpengaruh terhadap praktik perataan laba.

\section{Teori Keagenan}

Teori keagenan menyatakan bahwa hubungan keagenan muncul ketika terdapat kontrak kerja antara pemegang saham dengan pihak manajemen (Jensen dan Meckling, 1976). Para pemegang saham menginginkan manajer perusahaan untuk melakukan pelayanan atas kepentingan pemegang saham. Namun, pihak manajemen tidak selalu bertindak sesuai dengan keinginan pemegang saham apabila kepemilikannya atas perusahaan mengecil.

Menurut Eisenhardt (1989), teori keagenan dilandasi oleh tiga asumsi utama. Pertama, asumsi sifat manusia, yang menganggap bahwa manusia memiliki sifat yang berfokus pada kepentingan pribadi, memiliki keterbatasan rasionalitas, dan menghindari risiko. Kedua, asumsi keorganisasian, yang menganggap bahwa tujuan dari masing-masing pihak menimbulkan konflik diantara mereka, efisiensi dijadikan sebagai kriteria keefektivitasan kinerja, serta adanya asimetri informasi antara pemegang saham dan pihak manajemen. Ketiga, asumsi informasi (information assumption), bahwa informasi dianggap sebagai komoditas yang dapat diperjualbelikan.

GCG merupakan mekanisme kontrol untuk menyelaraskan kepentingan manajemen dengan pemegang saham. Tata kelola perusahaan atau disebut corporate governance adalah praktik dalam aktivitas bisnis untuk mencapai keberhasilan visi dan misi perusahaan yang didasarkan pada asas trans- 
paransi, akuntabilitas, responsibilitas, independensi, serta kewajaran dan kesetaraan kepada para pemegang saham beserta pemangku kepentingan lainnya. Tata kelola perusahaan dibagi menjadi dua unsur, yaitu internal dan eksternal. Hopt dan Leyens (2004) menyatakan bahwa unsur internal menyangkut susunan dari dewan tertinggi perusahaan dan kontrol dari kepemilikan saham. Unsur eksternal menyangkut audit dari pihak eksternal, penerapan regulasi, pengawasan dari pasar modal, dan transparansi pengungkapan peristiwa perusahaan. Sejak Dechow et al. (1996) sampai Fang et al. (2015) menunjukkan bahwa pengawasan internal maupun eksternal perusahaan mampu mengendalikan manipulasi laba. Namun demikian, Siregar dan Utama (2008) menunjukkan bukti bahwa mekanisme GCG tidak mampu mengendalikan perilaku manajemen laba di Indonesia.

\section{Konsep Laba}

Definisi mengenai laba sendiri tidak dapat dijelaskan secara tepat karena adanya perbedaan perspektif dalam melihat konsep laba (Ghozali dan Chariri, 2007). Namun dalam hal ini, Suwardjono (2005) mengungkapkan bahwa konsep laba termasuk ke dalam tataran semantik apabila berkaitan dengan makna apa yang harus dilekatkan pada simbol atau elemen laba, sehingga laba bermanfaat (useful) dan bermakna (meaningful) sebagai informasi. Representasi laba sesuai konsep ini merupakan laba yang mendekati atau sama dengan harapan, investor dan pengguna laporan keuangan lainnya untuk meyakinkan bahwa kinerja perusahaan memang terealisasi.

Terkait pendefinisian laba, Dechow et al. (2010) menegaskan bahwa definisi kualitas laba juga bergantung pada konteks pengambilan keputusan. Atribut kualitas laba terbagi menjadi dua, yaitu berdasarkan accounting-based dan berdasarkan marketbased. Menurut Francis et al., (2004), atribut yang termasuk accounting-based terdiri dari kualitas akrual, persistensi laba, prediktabilitas laba, dan variabilitas laba atau smoothness. Smoothness adalah atribut laba yang digunakan untuk memastikan seberapa besar variabilitas laba pada laporan keuangan setiap tahunnya. Semakin kecil variabilitas laba (atau dikatakan smooth) berarti semakin berkualitas laba yang dilaporkan oleh perusahaan. Variabilitas laba dapat diukur dengan membagi standar deviasi laba bersih dengan standar deviasi arus kas operasi.

\section{Pengaruh ukuran perusahaan terhadap variabilitas laba}

Semakin besar ukuran perusahaan semakin tinggi visibilitas politisnya di hadapan publik maupun regulator. Oleh sebab itu, ukuran perusahaan digunakan sebagai proksi biaya politik. Hipotesis biaya politik dalam teori akuntansi positif mendukung kondisi bahwa ukuran perusahaan akan berpengaruh terhadap tingkat variabilitas laba. Semakin besar ukuran perusahaan, semakin besar pula kemungkinan perusahaan untuk memiliki variabilitas laba yang kecil karena perusahaan ingin mempertahankan reputasi di mata publik. Perusahaan besar cenderung menghindari kenaikan laba yang signifikan untuk menghindari perhatian otoritas pajak. Perusahaan besar juga cenderung menghindari penurunan laba signifikan untuk menghindari perhatian pers dan evaluasi dari pasar modal. Lassaad dan Khamoussi (2013) juga mengkonfirmasi hipotesis biaya politis.

Namun demikian, ukuran perusahaan menghadapi ketidakpastian operasional yang tinggi dan cenderung memiliki laba yang bervariasi. Lebih jauh, Kuncoro (2006) menunjukkan bahwa Indonesia memiliki ketidakpastian ekonomi dan politik tinggi. Karakter ekonomi yang sarat dengan ketidakpastian hukum dan korupsi akan menyebabkan perusahaan besar cenderung menghasilkan laba yang bervariasi. Pagalung dan Sudibdyo (2012) membuktikan bahwa perusahaan besar cenderung memiliki variabilitas laba yang tinggi. Dengan demikian, penelitian ini mengajukan hipotesis: 
$\mathrm{H}_{1}$ : Ukuran perusahaan berpengaruh positif terhadap variabilitas laba.

\section{Pengaruh Kontrak Hutang terhadap Varia- bilitas Laba}

Hipotesis kontrak hutang dalam teori akuntansi positif mendukung suatu kondisi bahwa besarnya kontrak hutang yang dimiliki perusahaan akan berpengaruh terhadap tingkat variabilitas laba. Semakin besar hutang yang dimiliki perusahaan, semakin besar pula kemungkinan perusaha an untuk meningkatkan kualitas labanya dengan menunjukkan variabilitas laba yang kecil. Hal ini terjadi karena perusahaan harus memenuhi syarat-syarat kontrak dengan kreditur seperti mempertahankan rasio hutang atas modal, modal kerja, ekuitas pemegang saham, dan sebagainya. Dou et al. (2013) menunjukkan bahwa perusahaan yang bergantung pada kontrak pendanaan untuk tujuan investasi cenderung meratakan laba sebagai sinyal yang menandakan bahwa perusahaan berkomitmen terhadap kontrak. Hal ini dikonfirmasi oleh Roberts (2015) yang menunjukkan bahwa ketika debitor mengalami kenaikan leverage, kreditor cenderung menegosiasi ulang kontrak hutang dengan syarat yang lebih ketat. Dengan demikian, debitor memiliki insentif untuk mengelola laba sedemikian rupa hingga terhindar dari sangsi kreditor dengan mengurangi variabilitas laba.

Watts dan Zimmerman (1978) berhipotesis bahwa perusahaan dengan tingkat hutang yang tinggi memiliki insentif untuk mengadopsi kebijakan akuntansi income increasing untuk menghindari pelanggaran kontrak hutang. Dechow et al. (2010) juga menunjukkan bahwa literatur akuntansi secara umum mendukung hipotesis income increasing ini. Dengan demikian, hipotesis yang diusulkan adalah:

$\mathrm{H}_{2}$ : Kontrak hutang berpengaruh positif terhadap variabilitas laba.

\section{Pengaruh GCG perusahaan terhadap variabilitas laba}

Tujuan dari tata kelola perusahaan adalah memberikan informasi keuangan perusahaan yang didasarkan pada asas transparansi, akuntabilitas, responsibilitas, independensi, serta kewajaran dan kesetaraan kepada para pemegang saham beserta pemangku kepentingan lainnya. Berikut merupakan beberapa elemen yang digunakan dalam mengukur keefektivitasan dari penerapan Corporate Governance (CG). Pertama, komite audit menjalankan fungsi pengawasan dengan melakukan reviu atas laporan keuangan sebelum disampaikan kepada pihak eksternal serta memberikan masukan atas rencana kerja dan hasil kerja dari auditor internal. Keputusan BAPEPAMLK Nomor 643/BL/2012 (Republik Indonesia, 2012) menyatakan bahwa komite audit minimal terdiri dari 3 (tiga) orang anggota yang berasal dari komisaris independen dan pihak dari luar emiten atau perusahaan publik serta diketuai oleh komisaris independen. Klein (2002) menunjukkan bahwa komite audit mampu mengendalikan perilaku oportunis manajer.

Kedua, dewan komisaris independen melakukan pengawasan secara umum dan/atau khusus serta memberi masukan kepada dewan direksi. Peraturan OJK Nomor 33/POJK.04/2014 (Republik Indonesia, 2014) menyatakan bahwa dewan komisaris perusahaan sekurang-kurangnya terdiri dari 2 (dua) orang anggota yang salah satu diantaranya adalah komisaris independen. Armstrong et al. (2014) menunjukkan bahwa komisaris independen berperan penting dalam tata kelola perusahaan melalui peningkatan transparansi dan mengurangi manipulasi laba.

Ketiga, kepemilikan manajerial adalah kepemilikan saham oleh pihak manajemen perusahaan. Pihak manajemen akan termotivasi untuk meningkatkan kinerjanya dan akan lebih berhati-hati dalam mengambil keputusan karena ada manfaat dan kerugian secara langsung yang akan dirasakan manajer atas kondisi ekonomi perusahaan. Dugaan atas fungsi kepemilikan manajerial didukung oleh Lafond dan 
Roychowdhury (2008) yang menunjukkan bahwa kepemilikan manajerial meningkatkan konservatisme pelaporan keuangan dengan demikian laba cenderung stabil.

Keempat, kepemilikan institusional merupakan kepemilikan saham oleh investor institusi. Kepemilikan institusional akan mendorong peningkatan pengawasan agar lebih optimal terhadap kinerja manajemen. Ramalingegowda dan Yu (2012) menunjukkan bahwa pengawasan dari pemilik institusional menurunkan laba karena tingkat konservatisme yang meningkat.

Kelima, kualitas audit merupakan probabilitas kemampuan auditor eksternal dalam menemukan error ataupun fraud pada laporan keuangan dan mengungkapkannya dalam laporan audit (DeFond dan Zhang, 2014). Lin dan Hwang (2010) melaporkan bahwa banyak penelitian yang berhasil mengonfirmasi kemampuan para auditor dalam mengendalikan perilaku oportunis manajemen.

Secara keseluruhan, literatur CG menunjukkan bahwa kualitas CG mampu mengendalikan perilaku oportunis manajerial baik melalui mekanisme internal seperti kepemilikan manajerial, komite audit, komisaris independen, dan kepemilikan institusional maupun melalui mekanisme eksternal seperti kualitas audit. CG yang baik akan menekan manajemen untuk melaporkan laba secara konservatif dan melaporkan laba secara lebih jujur dan laba menjadi lebih befluktuasi. Dengan demikian, penelitian ini berhipotesis bahwa:

\section{$\mathrm{H}_{3}$ : GCG berpengaruh positif terhadap variabilitas laba.}

\section{METODE PENELITIAN}

Penelitian ini menggunakan metode kuantitatif yang merupakan penelitian yang terstruktur dan mengkuantifikasikan data untuk dapat digeneralisasikan (Anshori dan Iswati, 2009). Oleh sebab itu, penelitian ini menggunakan ukuran kuantitatif terhadap variabel-variabel yang diteliti dan teknik analisis statistika.

\section{Operasionalisasi Variabel Penelitian}

Variabilitas Laba (smoothness/ Sm)

Penelitian ini menggunakan smoothness sebagai proksi variabilitas laba yang dijadikan sebagai variabel dependen. Proksi ini dihitung menggunakan rasio atas volatilitas arus kas dibandingkan dengan volatilitas laba bersih. Rasio tersebut mencerminkan apakah pendapatan yang diterima perusahaan setiap tahunnya menunjukkan angka yang fluktuatif dalam bandingannya dengan arus kas operasi. Variabel ini dihitung menggunakan rasio atas volatilitas arus kas dibandingkan dengan volatilitas net income selama lima tahun sebelum periode penelitian (Lassaad dan Khamoussi, 2013; Pagalung dan Sudibdyo, 2012).

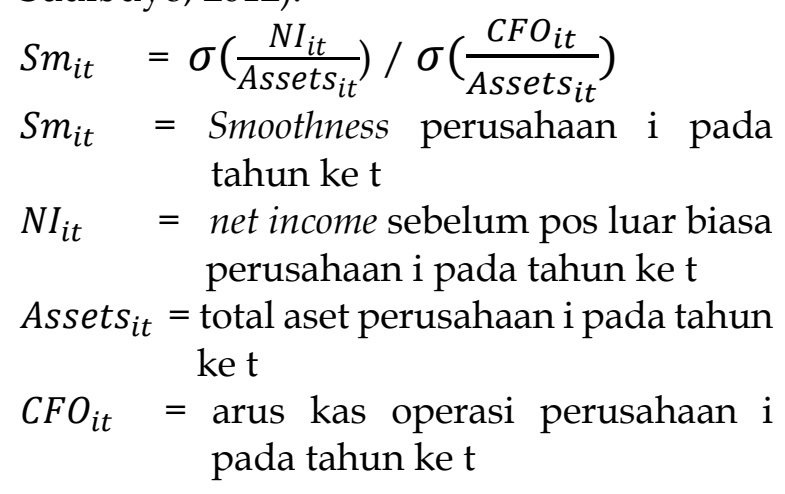

Semakin besar nilai Sm berarti semakin kecil variabilitas laba. Dengan kata lain, variabilitas laba yang tinggi ditunjukkan oleh nilai Sm yang rendah.

\section{Ukuran Perusahaan (Size)}

Ukuran perusahaan diukur dengan logaritma natural $(\mathrm{ln})$ total aset perusahaan. Dalam penelitian ini, ukuran perusahaan merupakan variabel independen untuk mewakili teori akuntansi positif yang diberi simbol "Size".

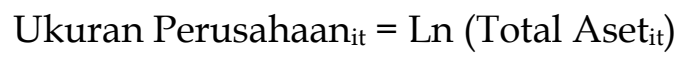

\section{Kontrak Hutang (Dcov)}

Kontrak hutang diukur menggunakan total debt to equity ratio. Rasio dihitung dari total hutang jangka pendek dan jangka panjang dibagi dengan total ekuitas. Rasio tersebut dihitung dari total hutang jangka 
pendek dan jangka panjang dibagi dengan total ekuitas yang diperoleh dari bagian laporan posisi keuangan (neraca) perusahaan.

Total Debt to Equity it $=\frac{\text { Total Liabilitas }_{i t}}{\text { Total Aset }_{i t}}$

\section{Good Corporate Governance}

Tata kelola perusahaan diukur dengan beberapa elemen yang terdiri dari komite audit, dewan komisaris independen, kepemilikan manajerial, kepemilikan institusional, dan kualitas audit. Tata kelola perusahaan dibagi menjadi dua unsur, yaitu internal dan eksternal. Hopt dan Leyens (2004) menyatakan bahwa unsur internal menyangkut susunan dari dewan tertinggi perusahaan dan kontrol dari kepemilikan saham. Unsur eksternal menyangkut audit dari pihak eksternal, penerapan regulasi, dan transparansi pengungkapan peristiwa perusahaan. Sehingga variabel Good Corporate Governance dalam penelitian ini merupakan penggabungan dari unsur internal (komite audit, dewan komisaris independen, kepemilikan manajerial, kepemilikan institusional) dan unsur eksternal (kualitas audit).

\section{Komite Audit (KA)}

Keputusan Ketua Bapepam dan Lembaga Keuangan Nomor 643/BL/2012 (Republik Indonesia, 2012) menyatakan bahwa komite audit minimal terdiri dari 3 (tiga) orang anggota. Variabel komite audit diukur dengan variabel dummy. Perusahaan yang memiliki komite audit 3 orang atau lebih pada tahun $\mathrm{t}$ diberi nilai 1 dan selain itu nol.

\section{Dewan Komisaris Independen (DK)}

Dewan komisaris independen diukur menggunakan rasio antara dewan komisaris yang berasal dari luar perusahaan dengan seluruh dewan komisaris yang terdapat di perusahaan.

DK =

Anggota Dewan Komisaris dari luar perusahaan Seluruh anggota Dewan Komisaris perusahaan
Kepemilikan Manajerial (KM)

Kepemilikan manajerial diukur menggunakan rasio antara jumlah lembar saham yang dimiliki pihak manajemen dengan jumlah lembar saham yang beredar.

$\mathrm{KM}=\frac{\text { Jumlah saham yang dimiliki pihak manajemen }}{\text { Total modal saham perusahaan yang beredar }}$

Kepemilikan Institusional (KI)

Kepemilikan institusional diukur dengan menggunakan rasio antara jumlah lembar saham yang dimiliki investor institusi dengan jumlah lembar saham yang beredar.

$\mathrm{KI}=\frac{\text { Jumlah saham yang dimiliki investor institusi }}{\text { Total modal saham perusahaan yang beredar }}$

Kualitas Audit

Dalam penelitian-penelitian sebelumnya, kualitas audit hanya menggunakan pengukuran tunggal misalnya ukuran kantor akuntan publik (KAP) dengan proksi big-4 dan nonbig-4. Herusetya (2012) mengembangkan pengukuran kualitas audit yang bersifat multidimensi dengan menggunakan composite measure dalam bentuk skor dari beberapa pengukuran kualitas audit. Pengukuran ini disebut AQMS (Audit Quality Metric Score). Variabel kualitas audit diukur menggunakan AQMS pada level perusahaan yang merupakan penjumlahan skor dimensi-dimensi kualitas audit yang dimiliki perusahaan. Pengukuran elemen masing-masing dimensi AQMS dijelaskan pada tabel 1.

Salah satu dimensi kualitas audit adalah spesialisasi auditor. Herusetya (2012) menggabungkan spesialisasi auditor dengan dimensi kualitas audit yang lain. Spesialisasi industri KAP adalah pengukuran dari kompetensi auditor yang menunjukkan apakah KAP tersebut menerima klien dari industri tertentu saja.

Suatu KAP dinyatakan memiliki kualitas audit yang baik apabila terkonsentrasi pada industri tertentu dari pada KAP yang menerima klien dari berbagai industri. Spesialisasi industri diukur dengan rumus: 
SPCL $=$

Jumlah aset klien KAP dalam industri tertentu

$\overline{\text { Jumlah aset klien untuk seluruh KAP dalam satu industri }}$
SPCL bernilai 1 jika KAP memiliki industry share terbesar yang diukur dengan rasio di atas, dan diberi skor 0 jika lainnya.

Tabel 1

Pengukuran Elemen AQMS

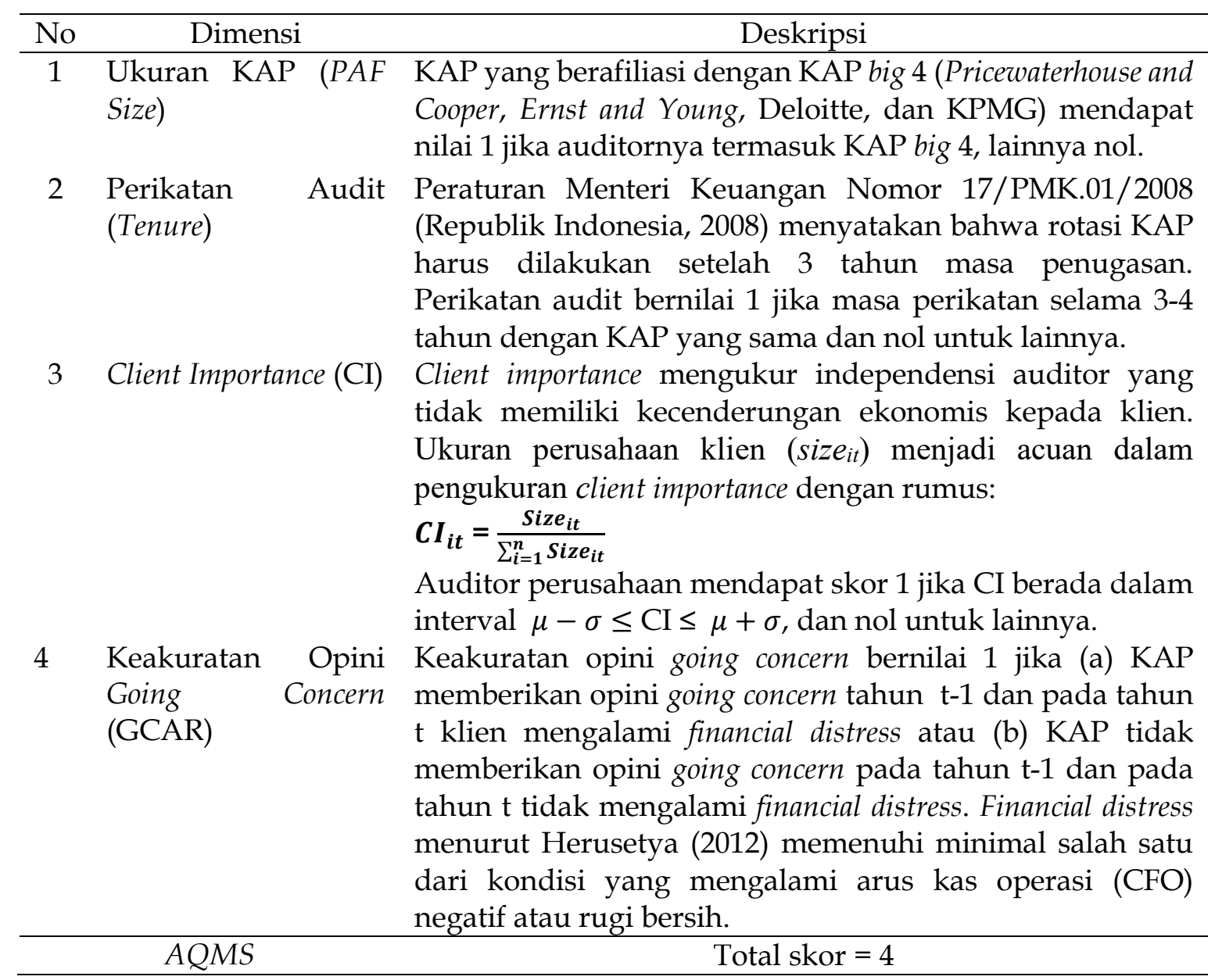

Sumber: Herusetya (2012)

Penelitian ini berbeda pandangan dengan Herusetya (2012). DeAngelo (1981) menyatakan bahwa kompetensi auditor adalah setara karena telah lulus ujian kualifikasi oleh regulator. Lebih lanjut, ex ante, SPCL tidak mengukur secara langsung kompetensi auditor karena proporsi jumlah aset klien tidak mencerminkan kompetensi khusus auditor. Spesialisasi auditor akan lebih baik jika diukur menggunakan proporsi pendapatan KAP yang diperoleh dari industri tertentu maupun jumlah klien KAP dari industri tertentu namun tidak terdapat data publik untuk mengukur spesialisasi auditor secara ideal. Oleh sebab itu, penelitian ini tidak menggunakan SPCL untuk mengukur kualitas audit.

\section{Populasi dan Sampel}

Populasi dalam penelitian ini adalah seluruh perusahaan yang terdaftar di Bursa Efek Indonesia periode 2012-2014. Sampel dalam penelitian ini ditentukan dengan teknik purposive sampling. Kriteria yang digunakan dalam pemilihan sampel tersebut adalah seluruh perusahaan yang telah menerbitkan laporan keuangan auditan sejak tahun 2008 sampai 2014. Data untuk 
variabel independen diperoleh dari laporan keuangan tahunan auditan perusahaan mulai periode 2012-2014. Data untuk variabel dependen membutuhkan laporan keuangan tahunan auditan perusahaan mulai periode 2008-2014. Berdasarkan kriteria pemilihan sampel tersebut, diperoleh se- banyak 628 sampel untuk periode observasi 2012-2014. Dalam penelitian ini ditemukan data-data outlier yang tidak digunakan oleh peneliti karena alasan tertentu. Data outlier tersebut terdiri dari 74 data yang memiliki variabilitas laba jauh diatas rata-rata, dengan rata-rata 0,57078 .

Tabel 2

Prosedur Seleksi Sampel

\begin{tabular}{|c|c|c|}
\hline No & Klasifikasi & Perusahaan \\
\hline 1 & Firm-year yang terdaftar di BEI periode 2012-2014 & 1433 \\
\hline 2 & $\begin{array}{l}\text { Firm-year yang mengalami delisting dari BEI selama } \\
\text { periode 2012-2014 }\end{array}$ & $(17)$ \\
\hline 3 & $\begin{array}{l}\text { Firm-year yang laporan keuangan tahunan auditannya } \\
\text { selama periode 2012-2014 tidak diperoleh dari berbagai } \\
\text { sumber }\end{array}$ & (73) \\
\hline 4 & $\begin{array}{l}\text { Firm-year yang laporan keuangan tahunan auditannya } \\
\text { selama periode 2008-2011 tidak diperoleh dari berbagai } \\
\text { sumber (untuk menghitung standar deviasi smoothness) }\end{array}$ & $(445)$ \\
\hline 5 & $\begin{array}{l}\text { Firm-year yang tidak mencantumkan opini auditor pada } \\
\text { laporan keuangan tahunan auditannya periode 2011-2014 }\end{array}$ & $(196)$ \\
\hline 6 & Firm-year termasuk outlier & (74) \\
\hline & Jumlah sampel & 628 \\
\hline
\end{tabular}

\section{Model Analisis}

Model analisis yang digunakan dalam penelitian ini adalah analisis regresi linier berganda (multiple regression analysis). Hipotesis penelitian ini diuji dengan model (1) yaitu:

$\operatorname{Sm}_{i t}=\beta_{0}+\beta_{1}$ Size $_{i t}+\beta_{2} \operatorname{Dcov}_{i t}+\beta_{3} G C G_{i t}+$ $\varepsilon_{i t}$

Keterangan:

$\mathrm{Sm}_{i t}=$ smoothness perusahaan i pada tahun $\mathrm{t}$

Size $_{i t}=$ ukuran perusahaan i pada tahun $\mathrm{t}$

$\operatorname{Dcov}_{i t}=$ kontrak hutang perusahaan i pada tahun $\mathrm{t}$

$G C G_{i t}=$ vektor variabel-variabel CG Perusahaan i pada tahun $\mathrm{t}$

$\beta_{0} \quad=$ konstanta

$\beta_{(1,2,3)}=$ koefisien regresi

$\varepsilon_{i t} \quad=$ error

Model (1) penelitian ini diuji menggunakan dua teknik yaitu regresi biasa dan regresi data panel. Regresi data panel mengikutsertakan fixed effect tahun dan mengestimasi standard error dengan teknik clustering pada level perusahaan. Menyertakan fixed effect tahun dalam model (1) akan mengendalikan faktor yang tidak terobservasi namun tetap ada sepanjang waktu dan menimbulkan bias pada koefisien estimasian variabel independen. Mengestimasi standard error dengan teknik clustering pada level perusahaan mengendalikan heteroskedastisitas yaitu ketidaksamaan varian $\varepsilon$ lintas perusahaan.

Uji hipotesis dilakukan dengan menggunakan model (1). Kriteria pengujian tiga hipotesis adalah (a) jika signifikansi $\beta_{1,2,3}$ dalam model (1) lebih kecil atau sama dengan $5 \%$ dan (b) $\beta_{1,2,3}$ bernilai lebih kecil dari nol. Koefisien regresi yang negatif menunjukkan pengaruh negatif variabel independen terhadap smoothness atau berpengaruh positif terhadap variabilitas laba. Vektor variabel CG dalam penelitian ini diuji 
dengan beberapa teknik. Pertama, vektor variabel CG akan dijadikan satu variabel dengan membentuk indeks gabungan CG melalui menjumlahkan skor variabel CG, mereratakannya, dan menggunakan principle component analysis (PCA). Kedua, vektor variabel CG akan dianalisis dalam bentuk dua faktor yaitu internal dan eksternal. Faktor CG eksternal adalah kualitas audit AQMS, selain itu dimasukkan dalam faktor internal yaitu komite audit, komisaris independen, kepemilikan manajerial, dan kepemilikan institusional. Ketiga, vektor variabel CG internal akan dianalisis secara indi vidual bersama dengan kualitas audit AQMS. Keempat, seluruh variabel CG dan AQMS dianalisis secara individual.

\section{ANALISIS DAN PEMBAHASAN Analisis Hasil Penelitian}

Tabel 3 bahwa smoothness mencapai nilai minimum sebesar 0,01 dan nilai maksimum sebesar 2,23. Nilai minimum 0,01 dicapai oleh Bank Ekonomi Raharja Tbk tahun 2012 dan nilai maksimum 2,23 dicapai oleh PT Yulie Sekurindo Tbk. Hasil penelitian Lassaad dan Khamoussi (2013) menunjukkan bahwa semakin besar nilai smoothness maka semakin kecil tingkat variabilitas laba, begitupun sebaliknya. Tingkat kontrak hutang
(Dcov) yang diukur menggunakan debt to equity ratio mencapai nilai maksimum sebesar 22,461 atau sebesar 224,61\%. Debt to equity ratio menentukan seberapa baik kreditur dilindungi dari kebangkrutan atau ketidakmampuan melunasi hutang. Dalam sampel penelitian terdapat beberapa perusahaan yang kesuluruhan ekuitasnya digunakan sebagai jaminan atas hutang karena persentase rasio $>100 \%$. Nilai minimum tingkat kontrak hutang (Dcov) adalah 0,0102, berarti perusahaan tersebut hanya menggunakan 1,02\% bagian ekuitasnya untuk dijadikan jaminan hutang. Hal ini berarti terdapat kemungkinan perusahaan dengan nilai debt to equity ratio yang kecil banyak menggunakan pendanaan yang berasal dari penjualan saham perusahaan.

Dewan komisaris independen (DK), yang dihitung menggunakan rasio jumlah anggota dewan dari luar perusahaan dibagi dengan jumlah anggota dewan keseluruhan, memiliki nilai minimum 0,00 dan nilai maksimum 1,00. Dari hasil deskripsi statistik tersebut menunjukkan bahwa terdapat beberapa perusahaan yang tidak memiliki dewan komisaris independen (nilai minimum 0,00 ) dan terdapat pula beberapa perusahaan yang keseluruhan dewan komisarisnya merupakan dewan komisaris independen (nilai maksimum 1,00).

Tabel 3

Deskripsi Statistik Variabel

\begin{tabular}{lcrrrr}
\hline \hline Variabel & $\mathbf{N}$ & $\begin{array}{c}\text { Nilai } \\
\text { Minimal }\end{array}$ & $\begin{array}{c}\text { Nilai } \\
\text { Maksimal }\end{array}$ & Rata-Rata & $\begin{array}{c}\text { Standar } \\
\text { Deviasi }\end{array}$ \\
\hline Sm & 628 & 0,01263 & 2,22646 & 0,57078 & 0,44453 \\
Size & 628 & 23,08250 & 34,38217 & 28,66788 & 1,94930 \\
Dcov & 628 & 0,01024 & 22,46110 & 2,29479 & 3,07805 \\
KA & 628 & 0 & 1 & 0.94 & 0.233 \\
DK & 628 & 0,00000 & 1,00000 & 0,42355 & 0,15440 \\
KM & 628 & 0,00000 & 0,50307 & 0,01471 & 0,05056 \\
KI & 628 & 0,00000 & 0,99996 & 0,68846 & 0,20426 \\
PAF Size & 628 & 0 & 1 & 0,40 & 0,491 \\
Tenure & 628 & 0 & 1 & 0,58 & 0,494 \\
GCAR & 628 & 0 & 1 & 0,70 & 0,460 \\
CLIM & 628 & 0 & 1 & 0,65 & 0,477 \\
\hline Sun
\end{tabular}

Sumber: data hasil penelitian (diolah) 
Kepemilikan manajerial (KM) mencapai nilai minimum sebesar 0,00 dan nilai maksimum sebesar 0,50 . Nilai minimum 0,00 menunjukkan bahwa perusahaan tidak memiliki kepemilikan manajerial. Nilai maksimum 0,50 menunjukkan bahwa terdapat perusahaan yang kepemilikan manajerialnya sebanyak $50 \%$, yaitu PT Riskia Bintang Mahkotasejati Tbk tahun 2013 dan 2014. Kepemilikan institusional (KI) mencapai nilai minimum sebesar 0,00 dan nilai maksimum sebesar 0,99. Nilai minimum tersebut menunjukkan bahwa perusahaan tidak memiliki kepemilikan institusional. Nilai maksimum 0,99 berarti sebesar 99\% kepemilikan perusahaan dimiliki oleh institusi atau badan. Perusahaan tersebut adalah Bank Mutiara Tbk, BPD Jawa Barat dan Banten Tbk, Bank Ekonomi Raharja Tbk, PT Keramika Indonesia Asosiasi Tbk, dan PT Tigaraksa Satria Tbk.

\section{Analisis Indeks Gabungan Corporate Governance}

Mekanisme corporate governance (CG) merupakan satu kesatuan mekanisme yang berusaha memitigasi konflik keagenan. Oleh sebab itu, mekanisme CG dalam penelitian ini dijadikan satu indeks. Menggabungkan variabel CG dalam model regresi ini bertujuan untuk mengidentifikasi elemen internal dan eksternal yang dapat menjelaskan variabel CG secara bersama-sama.

Untuk membentuk indeks gabungan CG, penelitian ini menggunakan beberapa cara yaitu dengan menjumlah variabelvariabel tata kelola perusahaan, merataratakannya, dan menggabungkannya berdasar analisis principal component analysis (PCA). Menjumlahkan nilai variabel-variabel CG menjadi sebuah indeks sudah lazim dilakukan oleh peneliti akuntansi seperti Gompers et al. (2003) maupun Jiraporn dan Gleason (2007). Sebagai contoh, Gompers et al. (2003) menyusun governance index (GIndex) dengan menjumlah skor 22 item provisi perlindungan pemegang saham di US. Membentuk indeks menggunakan nilai rerata beberapa variabel juga telah men- dapat pengakuan dari literatur statistika seperti Fukuda dan Onodera (2001) yang menyusun indikator ekonomi dengan mererata 11 ukuran makroekonomi.

Sebagai tambahan, PCA adalah prosedur statistik untuk mengonversi seperangkat variabel yang berkorelasi menjadi satu set variabel (Abdi dan Williams, 2010). PCA bisa jadi merupakan teknik statistik multivariat yang paling populer dan digunakan oleh hampir semua disiplin ilmu. PCA juga kemungkinan menjadi teknik multivariat tertua. Tujuannya adalah untuk mengekstrak informasi penting dari tabel, untuk mewakilinya sebagai seperangkat variabel ortogonal baru yang disebut komponen utama, dan untuk menampilkan pola kemiripan pengamatan dan variabel sebagai titik dalam peta. Penggunaan PCA untuk membentuk indeks dalam literatur akuntansi telah banyak diaplikasikan seperti Kim et al. (2011) dan Kim dan Zhang (2016).

Tahap pertama analisis adalah menguji pengaruh indeks gabungan CG terhadap variabilitas laba. Indeks gabungan CG meliputi SCG, MCG, dan PCG. SCG adalah indeks gabungan dengan menjumlah nilai variabel-variabel CG. MCG adalah indeks gabungan dengan mererata nilai variabel CG. PCG adalah indeks gabungan hasil PCA. Selain itu, ICG adalah indeks gabungan CG internal hasil PCA yang terdiri dari komite audit, komisaris independen, kepemilikan manajerial, dan kepemilikan institusional. SCG, MCG dan PCG meliputi CG internal dan kualitas audit AQMS. Hasil uji regresi model (1) ditampilkan di tabel 4.

Hasil analisis menunjukkan bahwa ukuran perusahaan berpengaruh positif (negatif) terhadap variabilitas laba (smoothness). Dengan kata lain, semakin besar ukuran perusahaan semakin bervariasi laba yang dilaporkan. Hal ini sesuai dengan hipotesis yang diusung penelitian ini.

Dechow et al., (2010) menyatakan bahwa bukti empiris mengenai hubungan ukuran perusahaan dan kualitas laba tidak konsisten. Sebagian literatur menyatakan bahwa perusahaan besar memiliki ketidakpastian 
operasional yang tinggi dan menyebabkan laba semakin bervariasi. Selain itu, Kuncoro (2006) menunjukkan bahwa lingkungan bisnis Indonesia memiliki ketidakpastian yang tinggi baik secara politik maupun ekonomi dan perusahaan akan cenderung menghasilkan laba yang berfluktuasi. Dengan demikian, ketidakpastian biaya politik di Indonesia menyebabkan ketidakpastian laba yang tinggi.

Selain berhasil mengkonfirmasi hipotesis, penelitian ini masih menemukan konsistensi hipotesis biaya politik (Watts dan Zimmerman, 1978). Hasil analisis juga menunjukkan bahwa tingkat hutang berpengaruh negatif terhadap smoothness atau berpengaruh positif terhadap variabilitas laba. Dengan kata lain, semakin tinggi tingkat hutang perusahaan, laba yang dilaporkan semakin bervariasi. Sekali lagi, penelitian ini berhasil mengkonfirmasi hipotesis yang diusulkan. Dechow et al., (2010) menjelaskan bahwa perusahaan yang memiliki tingkat hutang tinggi cenderung menaikkan laba untuk menghindari pelanggaran kontrak hutang. Dengan demikian, tingkat hutang yang tinggi memicu variabilitas laba yang tinggi.

Tabel 4

Analisis Indeks Gabungan

\begin{tabular}{|c|c|c|c|c|}
\hline Variabel & $\begin{array}{l}\text { (1) } \\
\text { Sm }\end{array}$ & $\begin{array}{l}\text { (2) } \\
\text { Sm }\end{array}$ & $\begin{array}{l}\text { (3) } \\
\text { Sm }\end{array}$ & $\begin{array}{l}\text { (4) } \\
\text { Sm }\end{array}$ \\
\hline Size & $\begin{array}{c}-0.021^{* *} \\
(0.010)\end{array}$ & $\begin{array}{c}-0.020^{* *} \\
(0.010)\end{array}$ & $\begin{array}{c}-0.018^{* *} \\
(0.009)\end{array}$ & $\begin{array}{c}-0.024^{* *} \\
(0.010)\end{array}$ \\
\hline Dcov & $\begin{array}{c}-0.053^{* * *} \\
(0.006)\end{array}$ & $\begin{array}{c}-0.053^{* * *} \\
(0.006)\end{array}$ & $\begin{array}{c}-0.053^{* * *} \\
(0.006)\end{array}$ & $\begin{array}{c}-0.051^{* * *} \\
(0.006)\end{array}$ \\
\hline$A Q M S$ & & & & $\begin{array}{l}0.029^{*} \\
(0.017)\end{array}$ \\
\hline SCG & $\begin{array}{c}0.019 \\
(0.016)\end{array}$ & & & \\
\hline MCG & & $\begin{array}{c}0.090 \\
(0.078)\end{array}$ & & \\
\hline PCG & & & $\begin{array}{l}-0.025 \\
(0.016)\end{array}$ & \\
\hline$I C G$ & & & & $\begin{array}{c}-0.027^{*} \\
(0.016)\end{array}$ \\
\hline Konstanta & $\begin{array}{c}1.204^{* * *} \\
(0.253)\end{array}$ & $\begin{array}{c}1.201^{* * *} \\
(0.253)\end{array}$ & $\begin{array}{c}1.206^{* * *} \\
(0.252)\end{array}$ & $\begin{array}{c}1.321^{* * *} \\
(0.260)\end{array}$ \\
\hline Observasi & 628 & 628 & 628 & 628 \\
\hline R-squared & 0.166 & 0.165 & 0.168 & 0.172 \\
\hline
\end{tabular}

Bukti empiris menunjukkan bahwa CG tidak dapat menjelaskan variabilitas laba. Indeks gabungan CG baik SCG, MCG, maupun PCG terbukti tidak memiliki kemampuan dalam menjelaskan variabilitas laba. Namun demikian, mekanisme internal CG (ICG) memiliki koefisien negatif dan signifikan pada level 10\%. Hal ini berarti mekanisme internal CG meningkatkan variabilitas laba. Hal ini menunjukkan bahwa mekanisme internal CG menekan manajemen untuk melaporkan laba tanpa manipulasi sehingga variabilitas laba mengikuti ketidakpastian lingkungan bisnis Indonesia. Namun demikian, mekanisme eksternal CG, kualitas audit, memiliki pengaruh yang berbeda dengan mekanisme internal CG. Ada kemungkinan hal ini disebabkan oleh masalah 
dalam model empiris penelitian yang memerlukan tindakan koreksi.

\section{Koreksi Heteroskedastisitas}

Penggunaan data cross-sectional dan time-series dalam regresi cenderung menghasilkan error yang berkorelasi dengan variabel independen sehingga menimbulkan bias dan ketidakkonsistenan koefisien regresi yang dihasilkan (Petersen, 2009). Sesuai dengan rekomendasi Gow et al. (2010), penelitian ini mengoreksi standard error regresi melalui analisis data panel. Untuk itu, penelitian ini memanfaatkan analisis data panel untuk mengontrol endogenitas dalam regresi seperti rekomendasi Roberts dan Whited (2012). Analisis lebih lanjut, penelitian ini menyertakan fixed effect tahun dan meng-cluster standard error pada level perusahaan. Fixed effect tahun disertakan dalam model regresi untuk mengontrol unobserved-invariant confounding effect. Mengcluster standard error pada level perusahaan penting untuk mengendalikan heteroskedastisitas data panel. Hasil analisis data panel ditampilkan di tabel 5 .

Tabel 5

Analisis Data Panel Indeks Gabungan

\begin{tabular}{lcccc}
\hline \hline & $\mathbf{( 1 )}$ & $\mathbf{( 2 )}$ & $\mathbf{( 3 )}$ & $\mathbf{( 4 )}$ \\
Variabel & $\mathbf{S m}$ & $\mathbf{S m}$ & $\mathbf{S m}$ & $\mathbf{S m}$ \\
\hline Size & $-0.021^{*}$ & $-0.020^{*}$ & -0.018 & $-0.024^{*}$ \\
Dcov & $(0.012)$ & $(0.012)$ & $(0.012)$ & $(0.012)$ \\
& $-0.053^{* * *}$ & $-0.053^{* * *}$ & $-0.053^{* * *}$ & $-0.051^{* * *}$ \\
AQMS & $(0.008)$ & $(0.008)$ & $(0.008)$ & $(0.008)$ \\
& & & & 0.029 \\
SCG & & & & $(0.019)$ \\
MCG & 0.019 & & & \\
CG & $(0.018)$ & & & \\
& & 0.088 & & \\
ICG & & $(0.089)$ & -0.025 & \\
& & & $(0.022)$ & \\
Konstanta & & & & -0.028 \\
& & & & $0.023)$ \\
Observasi & $1.199^{* * *}$ & $1.195^{* * *}$ & $1.201^{* * *}$ & $1.316^{* * *}$ \\
R-squared & $(0.327)$ & $(0.328)$ & $(0.337)$ & $(0.337)$ \\
\hline
\end{tabular}

Catatan: data hasil penelitian (diolah); Robust standard errors di dalam kurung; ${ }^{* * *}$ signifikan pada level 1\%; ** signifikan pada level 5\%; * signifikan pada level $10 \%$. Fixed effect tahun disertakan dalam model regresi. Standard error dikluster pada level perusahaan.

Hasil analisis menunjukkan bahwa ukuran dan tingkat hutang perusahaan masih konsisten berpengaruh positif (negatif) terhadap variabilitas laba (smoothness). Hal ini mendukung konsistensi teori akuntansi positif bahwa semakin besar ukuran perusahaan semakin bervariasi laba perusahaan karena ketidakpastian bisnis yang semakin tinggi. Tingkat hutang perusahaan yang semakin tinggi juga meningkatkan variabilitas laba karena perusahaan memiliki insentif yang tinggi untuk menaikkan laba agar terhindar dari pelanggaran kontrak hutang. Indeks gabungan CG kehilangan signifikansinya. Hal ini sesuai dengan temuan Siregar dan Utama (2008) yang menduga bahwa CG di Indonesia masih sebatas formalitas dan belum menjadi bagian dari 
sistem pelaporan keuangan. Namun demikian, dugaan ini perlu dikonfirmasi dengan data empiris. Lebih lanjut, koefisien AQMS kehilangan tanda signifikansinya ketika masalah heterokedastisitas dikoreksi. Hal ini membuktikan bahwa masalah heteroskedastisitas menimbulkan bias dan ketidak konsistenan koefisien regresi AQMS. Untuk menganalisis variabel CG, penelitian ini akan menguji variabel CG internal secara individual.

\section{Analisis Individual Corporate Governance}

Untuk mengelaborasi lebih lanjut variabel-variabel CG, penelitian ini menguji pengaruh variabel-variabel CG internal dan kualitas audit AQMS secara individual terhadap variabilitas laba. Tabel 6 menyajikan hasil analisis individual variabel CG internal. Tabel 6 kolom (1) menyajikan hasil analisis pengaruh variabel-variabel CG terhadap variabilitas laba tanpa kontrol atas pengaruh faktor pengganggu yang tidak bisa diobservasi. Koefisien ukuran dan tingkat perusahaan konsisten bernilai negatif dan signifikan sesuai dengan hasil uji sebelumnya. Kepemilikan institusional (KI) juga menunjukkan koefisien negatif dan signifikan. Hal ini membuktikan bahwa investor institusional memiliki kemampuan untuk mengendalikan perilaku manajer sehingga manajer melaporkan laba yang bervariasi sesuai dengan fluktuasi operasi bisnis. Bukti ini konsisten dengan Ajinkya et al. (2005) yang menunjukkan bahwa investor institusional meningkatkan transparansi dan akurasi pengungkapan. Lebih lanjut, Ramalingegowda dan Yu (2012) juga menunjukkan bahwa investor institusional meningkatkan konservatisme pelaporan keuangan.

Tabel 6

Analisis Individual Corporate Governance Internal

\begin{tabular}{lcc}
\hline \hline & $\mathbf{( 1 )}$ & $\mathbf{( 2 )}$ \\
Variabel & Sm & Sm \\
\hline Size & $-0.026^{* *}$ & $-0.026^{* *}$ \\
Dcov & $(0.010)$ & $(0.013)$ \\
& $-0.050^{* * *}$ & $-0.050^{* * *}$ \\
KA & $(0.006)$ & $(0.009)$ \\
& 0.037 & 0.037 \\
DK & $(0.072)$ & $(0.095)$ \\
& -0.079 & -0.077 \\
KM & $(0.111)$ & $(0.159)$ \\
& -0.343 & -0.343 \\
KI & $(0.347)$ & $(0.478)$ \\
& $-0.159^{*}$ & -0.159 \\
AQMS & $(0.085)$ & $(0.118)$ \\
& $0.029^{*}$ & 0.029 \\
Konstanta & $(0.017)$ & $(0.019)$ \\
& $1.467^{* * *}$ & $1.463^{* * *}$ \\
Observasi & $(0.286)$ & $(0.389)$ \\
R-squared & 628 & 628 \\
Fixed effect & 0.175 & 0.175 \\
Clustered standard error & - & Tahun \\
\hline
\end{tabular}

Catatan: data hasil penelitian (diolah); Robust standard errors di dalam kurung; *** signifikan pada level $1 \%$; ${ }^{* *}$ signifikan pada level $5 \%$; * signifikan pada level $10 \%$. Fixed effect tahun disertakan dan Standard error dikluster pada level perusahaan dalam model regresi kolom 2 . 
Lebih lanjut, AQMS memiliki koefisien yang positif dan signifikan pada level $10 \%$. Hal ini menunjukkan bahwa semakin tinggi kualitas audit semakin merata laba yang dilaporkan. Bisa jadi, audit yang berkualitas mengoreksi alokasi akrual maupun asumsi pelaporan keuangan sehingga laba menjadi lebih merata. Hal ini konsisten dengan bukti yang ditunjukkan oleh Chen et al. (2005) bahwa audit yang berkualitas mampu mengatisipasi unexpected accrual sehingga laba di laporan keuangan menjadi lebih merata.

Namun demikian, tanda signifikan kepemilikan institusional maupun AQMS hilang saat fixed effect tahun dimasukkan dalam model dan standard error di-cluster pada level perusahaan. Hal ini membuktikan bahwa signifikansi koefisien KI maupun AQMS terpengaruh heteroskedastisitas sehingga menjadi tidak signifikan ketika masalah heteroskedastisitas dikoreksi. Konsisten dengan bukti sebelumnya, bukti empiris menunjukkan bahwa mekanisme CG tidak memiliki kemampuan dalam menjelaskan variabilitas laba. Bagian akhir uji hipotesis penelitian ini menguji semua variabel independen secara individual baik variabel CG maupun kualitas audit. Hasil analisis statistika ditampilkan dalam tabel 7.

Hasil analisis menunjukkan bahwa ukuran perusahaan dan tingkat hutang perusahaan secara konsisten berpengaruh positif (negatif) terhadap variabilitas laba (smoothness). Hal ini konsisten dengan teori akuntansi positif. Selain itu, sebagian besar variabel CG tidak mampu menjelaskan variabilitas laba.

Hanya akurasi opini yang menunjukkan koefisien positif dan signifikan. Secara konseptual, hal ini bisa diinterpretasi sebagai kemampuan auditor dalam mengoreksi asumsi penyusunan laporan keuangan dan alokasi akrual sehingga laba yang dilaporkan lebih merata.

Tabel 7

Analisis Individual Seluruh Variabel

\begin{tabular}{lcc}
\hline \hline & $\mathbf{( 1 )}$ & $\mathbf{( 2 )}$ \\
Variabel & Sm & Sm \\
\hline Size & $-0.025^{* *}$ & $-0.024^{*}$ \\
Dcov & $(0.011)$ & $(0.014)$ \\
& $-0.048^{* * *}$ & $-0.048^{* * *}$ \\
KA & $(0.006)$ & $(0.008)$ \\
& 0.042 & 0.040 \\
DK & $(0.072)$ & $(0.096)$ \\
& -0.091 & -0.085 \\
KM & $(0.110)$ & $(0.156)$ \\
& -0.250 & -0.236 \\
KI & $(0.346)$ & $(0.474)$ \\
& -0.129 & -0.127 \\
PAF Size & $(0.085)$ & $(0.118)$ \\
& 0.036 & 0.035 \\
Tenure & $(0.039)$ & $(0.055)$ \\
GCAR & -0.033 & -0.044 \\
& $(0.033)$ & $(0.037)$ \\
CLIM & $0.142^{* * *}$ & $0.145^{* * *}$ \\
Konstanta & $(0.036)$ & $(0.040)$ \\
& -0.016 & -0.015 \\
& $(0.034)$ & $(0.042)$ \\
& $1.408^{* * *}$ & $1.384^{* * *}$
\end{tabular}




\begin{tabular}{lcc} 
& $(0.308)$ & $(0.431)$ \\
\hline Observasi & 628 & 628 \\
R-squared & 0.194 & 0.195 \\
Fixed effect & - & Tahun \\
Clustered standard error & - & Level perusahaan \\
\hline Catatan: data hasil penelitian (diolah); Robust standard errors di dalam \\
kurung; $* * *$ signifikan pada level 1\%; $* *$ signifikan pada level 5\%; * \\
signifikan pada level 10\%. Fixed effect tahun disertakan dan Standard error \\
dikluster pada level perusahaan dalam model regresi kolom 2.
\end{tabular}

Namun demikian, teknik pengukuran akurasi opini bisa jadi tidak akurat karena mengandalkan opini going concern yang relatif jarang terjadi. Jika auditor memberi opini going concern pada tahun $t$ dan terjadi financial distress pada tahun $\mathrm{t}+1$ atau jika auditor tidak memberi opini going concern pada tahun $t$ dan tidak terjadi financial distress pada tahun $\mathrm{t}+1$ maka akurasi opini mendapat nilai 1 . Pengukuran ini sangat umum dan mengikuti common sense dalam profesi audit. Patut diduga jika nilai akurasi opini audit berkorelasi positif dengan laba perusahaan yang dijadikan dasar perhitungan variabilitas laba.

\section{Analisis Median Corporate Governance}

Tidak adanya pengaruh CG terhadap variabilitas laba bisa jadi disebabkan pe- ngaruh dari sampel dengan CG yang tinggi dikoreksi oleh sampel dengan CG yang rendah. Oleh sebab itu, penelitian ini akan menganalisis secara terpisah sampel dengan skor CG tinggi dan rendah. Untuk itu, penelitian ini mengelompokkan sampel menjadi dua yaitu sampel dengan CG tinggi dan rendah dan meregresi setiap variabel independen terhadap variabel dependen. Untuk membentuk kelompok analisis, sampel yang memiliki CG di atas median digolongkan sebagai sampel dengan CG tinggi dan yang di bawah median memiliki CG rendah. Median ditentukan dari nilai indeks gabungan CG yaitu SCG, MCG, dan PCG. Regresi diestimasi dengan analisis panel data dan menyertakan fixed effect tahun serta standard error di-cluster pada level perusahaan. Hasil analisis ditampilkan di tabel 8 .

Tabel 8

Analisis Median Corporate Governance

\begin{tabular}{lcccccc}
\hline \hline & $\mathbf{( 1 )}$ & $\mathbf{( 2 )}$ & $\mathbf{( 3 )}$ & $\mathbf{( 4 )}$ & $\mathbf{( 5 )}$ & $\mathbf{( 6 )}$ \\
Variabel & SCG rendah & SCG tinggi & MCG rendah & MCG tinggi & $\begin{array}{c}\text { PCG rendah } \\
\text { Sm }\end{array}$ & $\begin{array}{c}\text { PCG tinggi } \\
\text { Sm }\end{array}$ \\
\hline Size & Sm & Sm & Sm & Sm & -0.024 \\
& $-0.042^{* *}$ & 0.003 & $-0.042^{* *}$ & 0.003 & -0.021 & -0.021 \\
Dcov & $(0.018)$ & $(0.024)$ & $(0.018)$ & $(0.024)$ & $(0.019)$ & $(0.020)$ \\
& $-0.033^{* * *}$ & $-0.069^{* * *}$ & $-0.033^{* * *}$ & $-0.069^{* * *}$ & $-0.056^{* * *}$ & $-0.049^{* * *}$ \\
KA & $(0.010)$ & $(0.013)$ & $(0.010)$ & $(0.013)$ & $(0.010)$ & $(0.011)$ \\
& -0.020 & 0.223 & -0.020 & 0.223 & 0.038 & 0.053 \\
DK & $(0.100)$ & $(0.217)$ & $(0.100)$ & $(0.217)$ & $(0.138)$ & $(0.118)$ \\
& -0.107 & -0.036 & -0.107 & -0.036 & $-0.473^{*}$ & 0.206 \\
KM & $(0.215)$ & $(0.197)$ & $(0.215)$ & $(0.197)$ & $(0.242)$ & $(0.190)$ \\
& 0.140 & -0.308 & 0.140 & -0.308 & 0.101 & $-2.288^{*}$ \\
KI & $(0.486)$ & $(0.657)$ & $(0.486)$ & $(0.657)$ & $(0.428)$ & $(1.163)$ \\
& $-0.308^{*}$ & 0.027 & $-0.308^{*}$ & 0.027 & -0.284 & 0.429 \\
PAF Size & $(0.172)$ & $(0.152)$ & $(0.172)$ & $(0.152)$ & $(0.209)$ & $(0.400)$ \\
& 0.074 & -0.047 & 0.074 & -0.047 & 0.096 & -0.017 \\
& $(0.095)$ & $(0.075)$ & $(0.095)$ & $(0.075)$ & $(0.066)$ & $(0.083)$
\end{tabular}




\begin{tabular}{lcccccc} 
Tenure & -0.069 & -0.052 & -0.069 & -0.052 & -0.059 & -0.023 \\
& $(0.057)$ & $(0.065)$ & $(0.057)$ & $(0.065)$ & $(0.050)$ & $(0.053)$ \\
GCAR & $0.092^{*}$ & $0.180^{* * *}$ & $0.092^{*}$ & $0.180^{* * *}$ & 0.092 & $0.152^{* * *}$ \\
& $(0.054)$ & $(0.065)$ & $(0.054)$ & $(0.065)$ & $(0.059)$ & $(0.057)$ \\
CLIM & -0.011 & -0.088 & -0.011 & -0.088 & -0.004 & -0.048 \\
& $(0.058)$ & $(0.079)$ & $(0.058)$ & $(0.079)$ & $(0.054)$ & $(0.060)$ \\
Konstanta & $2.047^{* * *}$ & 0.439 & $2.047^{* * *}$ & 0.439 & $1.580^{* * *}$ & 0.798 \\
& $(0.559)$ & $(0.803)$ & $(0.559)$ & $(0.803)$ & $(0.574)$ & $(0.622)$ \\
\hline Observasi & 313 & 315 & 313 & 315 & 313 & 315 \\
R-squared & 0.168 & 0.274 & 0.168 & 0.274 & 0.242 & 0.205 \\
Fixed effect & Tahun & Tahun & Tahun & Tahun & Tahun & Tahun \\
Clustered & Level & Level & Level & Level & Level & Level \\
standard error & perusahaan & perusahaan & perusahaan & perusahaan & perusahaan & perusahaan \\
\hline
\end{tabular}

Catatan: data hasil penelitian (diolah); Robust standard errors di dalam kurung; ${ }^{* * *}$ signifikan pada level 1\%; ** signifikan pada level 5\%; * signifikan pada level 10\%. Fixed effect tahun disertakan dan Standard error dikluster pada level perusahaan dalam model regresi kolom 2.

Hasil analisis menunjukkan bahwa ukuran perusahaan konsisten berpengaruh positif (negatif) terhadap variabilitas laba (smoothness). Namun demikian, ukuran perusahaan kehilangan signifikansinya untuk sampel perusahaan yang memiliki CG tinggi. Hal ini menunjukkan bahwa perusahaan dengan tata kelola yang baik mampu memitigasi tekanan politik yang diterima oleh perusahaan besar sampai ukuran perusahaan sebagai proksi biaya politik kehilangan pengaruhnya terhadap perilaku pelaporan keuangan.

Di sisi lain, tingkat hutang perusahaan konsisten berpengaruh positif (negatif) terhadap variabilitas laba (smoothness). Hal ini menandakan bahwa tekanan kontraktual dengan kreditor secara signifikan mempengaruhi perilaku manajemen dalam melaporkan laba. Semakin tinggi tingkat hutang sebuah perusahaan semakin tinggi variabilitas laba perusahaan sebagai upaya menghindari pelanggaran kontrak hutang.

Satu-satunya variabel CG yang mempengaruhi variabilitas laba adalah akurasi opini audit. Secara konseptual, hal ini bisa diinterpretasi sebagai kemampuan auditor dalam mengantisipasi unexpected accrual yang akhirnya meminimkan variabilitas laba. Kendati demikian, keterbatasan pengukuran akurasi opini audit bisa jadi memicu hasil yang ditampilkan dalam tabel 8 .

\section{Pembahasan}

\section{Pengaruh Ukuran Perusahaan terhadap Variabilitas Laba}

Hasil analisis menunjukkan bahwa pengaruh ukuran perusahaan terhadap variabilitas laba adalah positif. Dengan kata lain, semakin besar ukuran perusahaan maka semakin tinggi variabilitas labanya. Hasil penelitian ini mendukung hipotesis penelitian ini dan sesuai dengan teori akuntansi positif yang diungkapkan oleh (Watts dan Zimmerman, 1978).

Perusahaan yang berukuran lebih besar akan berusaha untuk mempertahankan reputasinya di depan publik. Pihak manajemen akan membuat kebijakan-kebijakan bagi proses kinerja operasional perusahaan dan juga pada metode pencatatan yang akan digunakan agar peningkatan laba perusahaan terlihat atraktif. Hasil analisis konsisten dengan penelitian Pagalung dan Sudibyo (2012) bahwa ukuran perusahaan yang lebih besar akan memiliki variabilitas laba yang lebih tinggi karena kualitas laba yang rendah. Hal ini bisa jadi disebabkan oleh lingkungan bisnis di Indonesia yang berkarakter ketidakpastian baik secara ekonomi, politik, dan hukum (Kuncoro, 2006; Slater dan Simmons, 2013) menyebabkan tingginya risiko yang dihadapi perusahaan besar. Selain itu, perusahaan besar cenderung menjadi bagian dari proses politik Indonesia yang sarat tindakan kolusi dan 
suap (Slater dan Simmons, 2013). Hal ini akan tercermin sebagai volatilitas laba yang tinggi dalam bandingannya dengan arus kas.

\section{Pengaruh Kontrak Hutang terhadap Variabilitas Laba}

Hasil analisis menunjukkan bahwa pengaruh kontrak hutang terhadap variabilitas laba adalah positif. Semakin besar hutang perusahaan maka variabilitas laba akan kecil. Hasil penelitian ini mendukung hipotesis yang diusulkan.

Hasil penelitian ini sesuai dengan teori akuntansi positif yang diungkapkan oleh Watts dan Zimmerman (1978) yang menyatakan bahwa adanya kontrak hutang mendorong pihak manajemen untuk memenuhi kontrak dengan para pemberi dana. Perjanjian hutang mengharuskan perusahaan untuk mematuhi perjanjian-perjanjian tertentu seperti mempertahankan rasio hutang atas modal, modal kerja, ekuitas pemegang saham, dan sebagainya. Perusahaan dengan tingkat hutang tinggi memiliki insentif untuk mengatur pelaporan laba agar lebih tinggi demi terhindar dari pelanggaran kontrak hutang (Dechow et al., 1996). Reviu terhadap sejumlah literatur yang dilakukan oleh Dechow et al., (2010) menunjukkan bahwa tingkat hutang yang tinggi secara empiris menginsentif manajemen untuk mengadopsi kebijakan akuntansi yang menaikkan laba.

Leverage merupakan faktor penting pemicu renegosiasi kontrak hutang (Roberts dan Sufi, 2009). Hal ini dikonfirmasi oleh Roberts (2015) yang menunjukkan bahwa kreditor cenderung merenegosiasi kontrak hutang dan meningkatkan keketatan kontrak ketika debitor mengalami kenaikan leverage yang signifikan.

\section{Pengaruh Corporate Governance terhadap Variabilitas Laba}

Variabel CG tidak berpengaruh signifikan terhadap variabilitas laba. Dengan demikian, hipotesis penelitian ini tidak terbukti. CG yang baik diharapkan dapat mendukung pelaporan keuangan yang ber- kualitas dengan memberikan informasi laba yang berkualitas. Namun demikian, CG di Indonesia belum berperan sesuai dengan yang diharapkan.

Hasil dari semua model analisis menunjukkan bahwa CG tidak berpengaruh terhadap variabilitas laba. Kendati demikian, penelitian ini berhasil membuktikan bahwa akurasi opini audit berpengaruh negatif terhadap variabilitas laba. Ketidak konsistenan hasil penelitian ini sesuai dengan bukti empiris yang telah didokumentasikan oleh Suhardianto dan Harymawan (2011). Riset-riset tentang kemampuan variabel CG dalam menjelaskan perilaku pelaporan keuangan manajemen.

Komite audit dan dewan komisaris independen yang secara konseptual diharapkan mampu mempengaruhi perilaku pelaporan manajemen ternyata tidak memiliki kekuatan penjelasan. Siregar dan Utama (2008) menjelaskan bahwa dua faktor tersebut tidak mampu mempengaruhi perilaku pelaporan karena komite audit dan komisaris independen diangkat perusahaan secara rata-rata hanya untuk memenuhi formalitas aturan otoritas pasar modal. Dengan demikian, komite audit dan komisaris independen tidak menjadi bagian dari sistem pengendalian internal dalam menyajikan laporan keuangan. Riset di Indonesia, seperti Sanjaya (2008) atau Pamudji dan Trihartati (2010) kerap tidak mampu mengonfirmasi kemampuan komite audit maupun dewan komisaris independen dalam mempengaruhi perilaku pelaporan manajemen.

Kepemilikan manajerial dalam penelitian ini tidak mampu mempengaruhi perilaku pelaporan keuangan manajemen. Kepemilikan manajerial sampel penelitian ini memiliki nilai rata-rata yang relatif kecil yaitu $1,5 \%$. Dengan kepemilikan yang sangat minim, manajemen tidak memiliki cukup insentif untuk berperilaku sesuai dengan kepentingan pemegang saham. Christiawan dan Tarigan (2007) menunjukkan bahwa kepemilikan manajerial di Indonesia tidak cukup memberikan insentif bagi manajemen 
untuk memaksimalkan kinerja perusahaan. Hadiprajitno dan Anggraeni (2013) juga tidak berhasil menemukan kemampuan kepemilikan manajerial dalam mempengaruhi perilaku pelaporan keuangan.

Kepemilikan institusional sampel penelitian memiliki rata-rata $69 \%$ yang cukup signifikan mempengaruhi perilaku pelaporan manajemen. Namun demikian, investor institusional di Indonesia rata-rata bagian dari kelompok bisnis dan terkonsentrasi sehingga kepentingan investor mayoritas mendominasi perilaku manajemen. ButarButar dan Sudarsi (2012) mengonfirmasi ketidakmampuan kepemilikan institusional dalam mempengaruhi perilaku pelaporan keuangan.

Dari empat variabel kualitas audit hanya akurasi opini audit yang terbukti secara positif (negatif) mempengaruhi smoothness (variabilitas) laba. Bukti empiris ini sejalan dengan temuan Chen et al. (2005) yang menunjukkan bahwa audit yang berkualitas mampu mengantisipasi akrual yang tidak biasa dan menimbulkan variabilitas laba. Namun demikian, hasil ini masih dibatasi oleh kelemahan pengukuran akurasi opini audit yang terlalu umum dan mengandalkan keberadaan financial distress yang jarang terjadi.

\section{Implikasi Penelitian \\ Konsistensi Teori Akuntansi Positif}

Fakta penelitian ini menunjukkan bahwa teori akuntansi positif masih relevan digunakan dalam menjelaskan perilaku pelaporan keuangan di Indonesia. Hipotesis biaya politis didukung oleh hasil penelitian ini. Ukuran perusahaan dapat digunakan investor dan kreditur sebagai dasar menilai kualitas pelaporan keuangan yang diterbitkan. Laporan keuangan yang berkualitas akan menghasilkan laba yang juga berkualitas. Informasi laba yang diharapkan adalah apabila dapat digunakan untuk memperkirakan earnings power serta memprediksi laba dimasa yang akan datang (Siallagan dan Machfoedz, 2006). Jika semakin besar ukuran perusahaan men- dukung variabilitas laba yang besar, maka pihak pemberi dana dapat menjadikan ukuran perusahaan sebagai salah satu pertimbangan pengambilan keputusan.

Selain itu, hipotesis kontrak hutang juga didukung oleh penelitian ini. Semakin besar hutang yang dimiliki perusahaan mendukung semakin besarnya variabilitas laba. Hal ini menunjukkan bahwa kontrak hutang dapat dijadikan sebagai pertimbangan bagi para penyedia modal sebelum memberikan tambahan modal. Semakin besar kontrak hutang memicu perusahaan untuk menaikkan laba dalam bandingannya dengan kas yang diterima agar terhindar dari pelanggaran kontrak hutang.

\section{Retorika Mekanisme CG}

Keberadaan CG tidak mendukung pelaporan informasi laba dengan kualitas yang baik. Sisi internal CG menunjukkan bahwa semakin banyak jumlah komite audit, dewan komisaris independen, kepemilikan manajerial, dan kepemilikan institusional dalam suatu perusahaan tidak dapat mempengaruhi perilaku pelaporan laba akuntansi. Mekanisme CG cenderung hanya mematuhi aturan otoritas pasar modal tanpa disertai usaha maksimal untuk menegakkan prinsip-prinsip CG dalam sistem pengendalian internal. Penelitian ini berhasil menemukan bahwa jumlah komite audit dan komisaris independen mayoritas sampel telah sesuai dengan Keputusan Ketua Bapepam LK Nomor 643/BL/2012 (Republik Indonesia, 2012) dan Peraturan OJK Nomor 33/POJK.04/2014 (Republik Indonesia, 2014). Namun demikian, para pengguna laporan keuangan tidak bisa menjadikan penerapan CG sebagai tolok ukur adanya informasi laba yang berkualitas. Kendati mekanisme CG internal terkesan hanya retorika, mekanisme CG eksternal memberi sedikit harapan. Sisi eksternal CG menunjukkan bahwa akurasi opini audit bisa digunakan untuk memprediksi perataan laba. Dalam batasaan pengukuran akurasi opini, audit yang berkualitas mampu mengantisipasi unexpected acrual sehingga laba 
menjadi lebih merata. Dengan demikian, mekanisme CG di Indonesia secara umum belum mampu mempengaruhi perilaku pelaporan keuangan dan regulator pasar modal perlu mengambil tindakan untuk meningkatkan efektifitas tata kelola perusahaan di Indonesia.

\section{SIMPULAN DAN SARAN}

Berdasarkan hasil analisis data yang telah diperoleh, kesimpulan yang dapat diambil untuk menjawab rumusan masalah adalah sebagai berikut. Pertama, semakin besar ukuran suatu perusahaan maka semakin besar tingkat variabilitas laba. Hasil analisis ini sesuai dengan hipotesis teori akuntansi positif yang diungkapkan oleh Watts dan Zimmerman (1978) bahwa ukuran perusahaan yang semakin besar menghadapi risiko bisnis dan politik yang besar sehingga variabilitas laba meningkat. Namun demikian, hal ini hanya berlaku pada sampel dengan tingkat CG yang rendah. Kedua, semakin besar kontrak hutang yang dimiliki perusahaan maka semakin besar tingkat variabilitas laba. Hal ini disebabkan oleh adanya insentif perusahaan untuk menghindari pelanggaran kontrak hutang, seperti mempertahankan rasio hutang atas modal, modal kerja, ataupun ekuitas pemegang saham, dengan mengadopsi kebijakan akuntansi yang agresif. Ketiga, mekanisme CG tidak mempengaruhi variabilitas laba menandakan belum efektifnya tata kelola perusahaan di Indonesia.

Penelitian ini sebatas mengelaborasi hubungan antara ukuran perusahaan, tingkat hutang, dan mekanisme tata kelola perusahaan dengan variabilitas laba. Hasil yang ditampilkan penelitian ini sebaiknya tidak diinterpretasi sebagai kausalitas.

Endogenitas antara pilihan metode akuntansi yang berdampak pada variabilitas laba, ukuran perusahaan, pilihan kebijakan hutang, maupun pilihan mekanisme tata kelola perusahaan masih belum dimitigasi secara maksimal. Namun demikian, penelitian ini telah menggunakan teknik analisis yang cukup layak untuk memitigasi un- observed invariant confounding effect maupun heteroskedastisitas dengan fixed effect model maupun meng-cluster standard error. Untuk membangun kesimpulan kausalitas antara karakteristik perusahaan dan variabilitas laba, peneliti di masa mendatang memerlukan disain khusus untuk memitigasi endogenitas model misalnya menggunakan natural experiment dengan memanfaatkan inisiasi regulasi yang berlaku untuk semua perusahaan. Kendati demikian, sampai penelitian ini selesai, belum ada regulasi signifikan yang mempengaruhi tata kelola perusahaan secara eksogen dan pada akhirnya mempengaruhi perilaku pelaporan di Indonesia.

Penelitian ini maupun penelitian sebelumnya yang tidak mampu membuktikan efektifitas tata kelola perusahaan kerap terbatas dalam memperoleh bukti tambahan. Pengukuran efektifitas tata kelola perusahaan membutuhkan disain khusus misalnya riset kualitatif yang mengevaluasi secara mendetil efektifitas tata kelola suatu perusahaan. Tanpa terobosan dalam metode, penelitian efektifitas tata kelola perusahaan hanya akan mengulang temuan yang sudah ada.

Penelitian ini menemukan bahwa banyak laporan keuangan perusahaan periode 2008-2014 yang tidak dapat ditemukan dari sumber manapun. Dari laporan keuangan yang telah diperoleh, tidak semuanya disertai opini dari auditor eksternal. Hal ini menyebabkan penelitian yang memerlukan opini audit tidak dapat dilakukan dengan maksimal.

Hal ini perlu mendapat perhatian oleh otoritas pasar modal karena ketersediaan data akan mendorong riset di masa mendatang.

\section{DAFTAR PUSTAKA}

Abdi, H. dan L. J. Williams. 2010. Principal Component Analysis. Wiley Interdisciplinary Reviews: Computational Statistics 2(4): 433-459.

Ajinkya, B., S. Bhojraj, dan P. Sengupta. 2005. The Association between Outside 
Directors, Institutional Investors and the Properties of Management Earnings Forecasts. Journal of Accounting Research 43(3): 343-376.

Anshori, M. dan S. Iswati. 2009. Metodologi Penelitian Kuantitatif. Pusat Penerbitan dan Percetakan UNAIR. Surabaya.

Armstrong, C. S., J. E. Core, dan W. R. Guay. 2014. Do Independent Directors Cause Improvements in Firm Transparency? Journal of Financial Economics 113(3): 383403.

Butar-Butar, L. K. dan S. Sudarsi. 2012. Pengaruh Ukuran Perusahaan, Profitabilitas, Leverage, Dan Kepemilikan Institusional Terhadap Perataan Laba: Studi Empiris Pada Perusahaan Food and Beverages Yang Terdaftar Di BEI. Dinamika Akuntansi Keuangan dan Perbankan 1(2): 143-158.

Chen, K. Y., L. Kuen-Lin, dan J. Zhou. 2005. Audit Quality and Earnings Management for Taiwan Ipo Firms. Managerial Auditing Journal 20(1): 86-104.

Christiawan, Y. J. dan J. Tarigan. 2007. Kepemilikan Manajerial: Kebijakan Hutang, Kinerja Dan Nilai Perusahaan. Jurnal Akuntansi dan Keuangan 9(1): 1-8.

DeAngelo, L. E. 1981. Auditor Size and Audit Quality. Journal of Accounting and Economics 3(3): 183-199.

Dechow, P. M., W. Ge, dan C. Schrand. 2010. Understanding Earnings Quality: A Review of the Proxies, Their Determinants and Their Consequences. Journal of Accounting and Economics 50(2-3): 344-401.

Dechow, P. M., R. G. Sloan, dan A. P. Sweeney. 1996. Causes and Consequences of Earnings Manipulation: An Analysis of Firms Subject to Enforcement Actions by the SEC*. Contemporary Accounting Research 13(1): 1-36.

DeFond, M. dan J. Zhang. 2014. A Review of Archival Auditing Research. Journal of Accounting and Economics 58(2-3): 275326.

Dou, Y., O.-K. Hope, dan W. B. Thomas. 2013. Relationship-Specificity, Contract
Enforceability, and Income Smoothing. Accounting Review 88(5): 1629-1656.

Eisenhardt, K. M. 1989. Agency Theory: An Assessment and Review. Academy of Management Review 14(1): 57-74.

Fang, V. W., A. H. Huang, dan J. M. Karpoff. 2015. Short Selling and Earnings Management: A Controlled Experiment. The Journal of Finance 81(3): 1251-1293.

Francis, J., R. LaFond, P. M. Olsson, dan K. Schipper. 2004. Costs of Equity and Earnings Attributes. The Accounting Review 79(4): 967-1010.

Fukuda, S.-I. dan T. Onodera. 2001. A New Composite Index of Coincident Economic Indicators in Japan: How Can We Improve Forecast Performances? International Journal of Forecasting 17(3): 483498.

Ghozali, I., dan A. Chariri. 2007. Teori Akuntansi. Badan Penerbit Universitas Diponegoro. Semarang.

Gompers, P., J. Ishii, dan A. Metrick. 2003. Corporate Governance and Equity Prices. The Quarterly Journal of Economics 118(1): 107-156.

Gow, I. D., G. Ormazabal, dan D. J. Taylor. 2010. Correcting for Cross-Sectional and Time-Series Dependence in Accounting Research. The Accounting Review 85(2): 483-512.

Hadiprajitno, B. dan R. M. Anggraeni. 2013. Pengaruh Struktur Kepemilikan Manajerial, Ukuran Perusahaan, dan Praktik Corporate Governance terhadap Manajemen Laba. Diponegoro Journal of Accounting 2(3): 754-766.

Herusetya, A. 2012. Analisis Kualitas Audit terhadap Manajemen Laba Akuntansi: Studi Pendekatan Composite Measure Versus Conventional Measure. Jurnal Akuntansi dan Keuangan Indonesia 9(2): 117-135.

Holthausen, R. W., D. F. Larcker, dan R. G. Sloan. 1995. Annual Bonus Schemes and the Manipulation of Earnings. Journal of Accounting and Economics 19(1): 29-74.

Hopt, K. J. dan P. C. Leyens. 2004. Board Models in Europe-Recent Develop- 
ments of Internal Corporate Governance Structures in Germany, the United Kingdom, France, and Italy. European Company and Financial Law Review 1(2): 135-168.

Ikatan Akuntan Indonesia. 2016. Standar Akuntansi Keuangan Per Efektif 1 Januari 2017. Ikatan Akuntan Indonesia. Jakarta.

Jensen, M. C. dan W. H. Meckling. 1976. Theory of the Firm: Managerial Behavior, Agency Costs and Ownership Structure. Journal of financial economics 3(4): 305-360.

Jiraporn, P. dan K. C. Gleason. 2007. Capital Structure, Shareholder Rights, and Corporate Governance. Journal of Financial Research 30(1): 21-33.

Kim, C. dan L. Zhang. 2016. Corporate Political Connections and Tax Aggressiveness. Contemporary Accounting Research 33(1): 78-114.

Kim, J.-B., B. Y. Song, dan L. Zhang. 2011. Internal Control Weakness and Bank Loan Contracting: Evidence from SOX Section 404 Disclosures. Accounting Review 86(4): 1157-1188.

Klein, A. 2002. Audit Committee, Board of Director Characteristics, and Earnings Management. Journal of Accounting and Economics 33(3): 375-400.

Kuncoro, A. 2006. Corruption and Business Uncertainty in Indonesia. ASEAN Economic Bulletin 23(1): 11-30.

Lafond, R. dan S. Roychowdhury. 2008. Managerial Ownership and Accounting Conservatism. Journal of Accounting Research 46(1): 101-135.

Lassaad, B. M. dan H. Khamoussi. 2013. Communication About Environmental Information: What Drives the Effect on Income Smoothing as Proxy of Earnings Quality? Journal of Behavioral and Applied Management 14(3): 173-184.

Lin, J. W. dan M. I. Hwang. 2010. Audit Quality, Corporate Governance, and Earnings Management: A Meta-Analysis. International Journal of Auditing 14(1): 57-77.
Matsuura, S. 2008. On the Relation between Real Earnings Management and Accounting Earnings Management: Income Smoothing Perspective. Journal of International Business Research 7(3): 6377.

Pagalung, G. dan B. Sudibdyo. 2012. The Determinant Factors of Earnings Quality and Economic Consequences. EKUITAS (Jurnal Ekonomi dan Keuangan) 16(1): 105122.

Pamudji, S. dan A. Trihartati. 2010. Pengaruh Independensi dan Efektivitas Komite Audit terhadap Manajemen Laba. Jurnal Dinamika Akuntansi 2(1): 21-29.

Petersen, M. A. 2009. Estimating Standard Errors in Finance Panel Data Sets: Comparing Approaches. Review of Financial Studies 22(1): 435-480.

Ramalingegowda, S. dan Y. Yu. 2012. Institutional Ownership and Conservatism. Journal of Accounting and Economics 53(1-2): 98-114.

Republik Indonesia. Keputusan Ketua Bapepam dan Lembaga Keuangan Nomor KEP-643/BL/2012 tentang Pembentukan dan Pedoman Pelaksanaan Kerja Komite Audit. 2012. Kementerian Keuangan. Jakarta.

Peraturan Menteri Keuangan Nomor 17/PMK.01/2008 tentang Jasa Akuntan Publik. 2008. Kementerian Keuangan. Jakarta. POJK Nomor 33/POJK.04/ 2014 tentang Direksi dan Dewan Komisaris Emiten Atau Perusahaan Publik. 2014. Otoritas Jasa Keuangan. Jakarta.

Roberts, M. R. 2015. The Role of Dynamic Renegotiation and Asymmetric Information in Financial Contracting. Journal of Financial Economics 116(1): 61-81.

Roberts, M. R. dan A. Sufi. 2009. Renegotiation of Financial Contracts: Evidence from Private Credit Agreements. Journal of Financial Economics 93(2): 159184.

Roberts, M. R., dan T. M. Whited. 2012. Endogeneity in Empirical Corporate 
Finance University of Rochester Simon School Working Paper.

Salno, H. M. dan Z. Baridwan. 2000. Analisis Perataan Penghasilan (Income Smoothing): Faktor-Faktor yang Mempengaruhi dan Kaitannya dengan Kinerja Saham Perusahaan Publik di Indonesia. The Indonesian Journal of Accounting Research 3(1): 17-34.

Sanjaya, I. P. S. 2008. Auditor Eksternal, Komite Audit, dan Manajemen Laba. The Indonesian Journal of Accounting Research 11(1): 97-116.

Siallagan, H. dan M. Machfoedz. 2006. Mekanisme Corporate Governance, Kualitas Laba dan Nilai Perusahaan. Simposium Nasional Akuntansi 9 Padang: 23-26.

Siregar, S. V. dan S. Utama. 2008. Type of Earnings Management and the Effect of Ownership Structure, Firm Size, and Corporate-Governance Practices: Evidence from Indonesia. The International Journal of Accounting 43(1): 1-27.

Sivaramakrishnan, S. dan S. C. Yu. 2008. On the Association between Corporate Governance and Earnings Quality. https://ssrn.com/abstract $=1014243$.

Diakses 12 Desember 2016.

Slater, D. dan E. Simmons. 2013. Coping by Colluding: Political Uncertainty and Promiscuous Powersharing in Indonesia and Bolivia. Comparative Political Studies 46(11): 1366-1393.

Suhardianto, N. dan I. Harymawan. 2011. A Decade of Earnings Management Researches in Indonesia. Asia Pacific
Journal of Accounting and Finance 2(1): 90119.

Suhardianto, N., B. Subroto, dan G. Chandrarin. 2017. Mapping MarketBased Accounting Research in Indonesia: Graphics and Guidelines for Future Research. Asian Journal of Accounting Research 2(1).

Suwardjono. 2005. Teori Akuntansi: Perekayasaan Pelaporan Keuangan. BPFE. Yogyakarta.

Tang, H. W. dan C. C. Chang. 2015. Does Corporate Governance Affect the Relationship between Earnings Management and Firm Performance? An Endogenous Switching Regression Model. Review of Quantitative Finance and Accounting 45(1): 33-58.

Watts, R. L. dan J. L. Zimmerman. 1978. Towards a Positive Theory of the Determination of Accounting Standards. The Accounting Review 53(1): 112-134.

Watts, R. L. dan J. L. Zimmerman. 1986. Positive Accounting Theory. Prentice-Hall, Inc. New Jersey.

Yushita, A. N. dan H. Triatmoko. 2013. Pengaruh Mekanisme Corporate Governance, Kualitas Auditor Eksternal, dan Likuiditas terhadap Kualitas Laba. Jurnal Economia 9(2): 141-155.

Yusuf, M. dan S. Soraya. 2004. Faktor-Faktor yang Mempengaruhi Praktik Perataan Laba pada Perusahaan Asing dan Non Asing di Indonesia. Jurnal Akuntansi dan Auditing Indonesia 8(1): 99-125. 